\title{
PENGAMAN HUBUNG SINGKAT TEGANGAN SEARAH MENGGUNAKAN KOMPARATOR PADA MODUL RANGKAIAN ELEKTRONIK UNTUK PEMBELAJARAN
}

\author{
Andik Asmara ${ }^{1}$ \\ ${ }^{1}$ Jurusan Pendidikan Teknik Elektro FT UNY \\ Email: andikasmara@uny.ac.id
}

\begin{abstract}
Electronic circuit module for learning allows damage to occur, caused by the occurrence of source installation problem. Occurred in an unknown do to short circuit. Therefore, in the results of this study aims to build a circuit of short circuit, and see the results of the performance of the circuit. The method used is a research development that divided the stages of designing, manufacturing, testing and application. The results obtained from this research show that the circuit works well, with indicator by a breaker relay work when a DC voltage short circuit occurs, accompanied by a buzzer sound. Good circuit can look from performance short circuit sensor using zanier diode $3.3 \mathrm{~V}$ for regulator $5 \mathrm{~V}$ and $5.6 \mathrm{~V}$ for $12 \mathrm{~V}$ regulator.
\end{abstract}

Keywords: short circuit, DC voltage, learning

\begin{abstract}
ABSTRAK
Modul rangkaian elektronik untuk pembelajaran memungkinkan terjadi kerusakan, yang disebabkan oleh terjadinya kesalahan pemasangan sumber tegangan. Hal ini menyebabkan terjadinya hubung singkat yang tidak diketahui. Penelitian ini bertujuan untuk membangun sebuah rangkaian pengaman hubung singkat, dan melihat hasil unjuk kerja rangkaian tersebut. Metode yang digunakan adalah penelitian pengembangan yang menggunakan tahapan perancangan, pembuatan, pengujian dan penerapan. Hasil yang diperoleh dari penelitian ini menunjukkan bahwa rangkaian bekerja dengan baik ditandai dengan kerja relay pemutus saat terjadi hubung singkat tegangan searah, disertai dengan bunyi buzzer. Selanjutnya untuk mendapatkan kinerja rangkaian sensor hubung singkat yang baik digunakan diode zener $3,3 \mathrm{~V}$ untuk regulator $5 \mathrm{~V}$ dan $5,6 \mathrm{~V}$ untuk regulator $12 \mathrm{~V}$.
\end{abstract}

Kata kunci: hubung singkat, tegangan DC, pembelajaran

\section{PENDAHULUAN}

Robert Heinich (2001; hal-10) menyatakan bahwa media merupakan perangkat atau fasilitas untuk membantu berkomunikasi. Berdasarkan hal tersebut, media menjadi alat yang dapat digunakan untuk membantu penyampaian informasi atau pengetahuan dari pengajar ke peserta didik. Media pembelajaran praktik dapat bebentuk modul rangkaian elektronik. Modul rangkaian elektronik tersebut digunakan untuk melatih peserta didik dalam memahami suatu kerja rangkaian, mulai dari merancang, merangkai, mencatat hasil sampai dengan menganalisis hasil praktik. Berdasarkan tulisan Mustoliq (2007), media pembelajaran yang berkualitas media yang proses pengembangannya melalui proses seleksi, desain, produksi dan digunakan sebagai bagian dari sistem instruksional. Berdasarkan hal tersebut, media pembelajaran yang baik harus merupakan hasil desain yang benar dan tepat. Setiap bagian harus memperhatikan fungsi dan spesifikasi dari bagian-bagian yang saling terhubung. Diambil contoh, Modul Rangkaian Elektronik mikrokontroler harus memiliki tegangan sumber yang tepat yaitu $5 \mathrm{~V}$ untuk kerja mikroprosesornya dan $12 \mathrm{~V}$ untuk perangkat pendukungnya.

Sumber tegangan dari catu daya merupakan bagian yang membuat rangkaian 
elektronik bekerja atau beroperasi. Karena itu sumber tegangan harus dijaga dengan baik agar tidak terjadi kerusakan. Terdapat dua kemungkinan yang menyebabkan suatu sumber tegangan terjadi kerusakan, yaitu beban yang berlebih dan terjadinya hubung singkat. Gerards Gavrilovs (2011) menyatakan bahwa kerusakan suatu sistem catu daya rangkaian elektronik terjadi karena terkena sambaran petir, tegangan terlalu besar, dan terjadinya hubung singkat. Beban berlebih dalam jangka waktu tertentu dapat menyebabkan rangkaian catu daya pada sumber tegangan panas, dan kemudian bisa menyebabkan kerusakan.

Pengembangan media juga harus memperhatikan keselamatan bagi pengguna dan alat yang digunakan. Keselamatan bagi pengguna dilaksanakan dengan memberikan rambu-rambu atau standar opersional prosedur (SOP) yang tepat, sedangkan untuk alat atau modul praktik selain dengan SOP juga harus memiliki sistem pengaman atau keselamatan alat yang tepat dan baik. Sistem pengaman alat dapat berupa bahan atau material yang digunakan, bentuk yang ergonomis dan dapat diletakkan suatu pengaman elektronik. Pengaman elektronik sendiri dapat berupa pengaman arus lebih, pengaman hubung singkat, pengaman dari panas berlebihan dan pengaman dari kesalahan pemasangan.

Salah satu fokus pada penelitian pengembangan ini adalah mengembangkan suatu sistem pengaman modul rangkaian elektronik dari hubung singkat yang terjadi. Hasil observasi dan pengumpulan data pada matakuliah yang menggunakan modul rangkaian elektronik, menyatakan bahwa kesalahan praktik yang menyebabkan kerusakan terjadi karena kesalahan pemasangan sumber tegangan. Salah satu kesalahan yang menyebabkan kerusakan adalah hubung singkat pada jalur catu daya pada rangkaian, dan kesalahan itu tidak secara langsung terlihat atau terdeteksi. Akibatnya dalam jangka waktu lama, dapat menyebabkan kerusakan pada modul rangkaian elektronik atau rangkaian catu daya.
Sistem pengaman hubung singkat membutuhkan suatu sensor deteksi yang cepat dan akurat. Hal ini sependapat dengan tulisan dari Yan Wang (2011), yang mengatakan bahwa Arus hubung singkat dalam sistem catu daya akan meningkat pada batas berbahaya dalam waktu beberapa milidetik. Tidak ada sensor secara spesifik untuk mendeteksi terjadinya hubung singkat. Tetapi sensor tersebut dapat dibangun dengan sendirinya, dengan melihat ciri-ciri yang terjadi. Ciri terjadinya hubung singkat dapat dilihat dari arus yang meningkat dan tegangan yang menurun mendekati nol atau ground. Salah satu ciri terjadi penurunan tegangan mendekati nol atau ground inilah yang digunakan untuk mendeteksi terjadinya hubung singkat.

Komparator menurut Neha (2016) adalah rangkaian elektronik yang membandingkan satu sinyal analog dengan satu sinyal analog lainnya, dan kemudian menghasilkan keluaran berupa logika biner. Logika biner disini dapat diterjemahkan menjadi keluaran tegangan tinggi atau rendah yang digunakan untuk proses selanjutnya. Oleh karena itu, sistem deteksi hubung singkat dapat menggunakan komparator untuk membendingkan tegangan referensi dengan tegangan jaringan yang dapat memungkinkan terjadinya hubung singkat.

Berdasarkan latar belakang tersebut dan kajian teori yang dikembangkan, dilakukan penelitian pengembangan untuk membangun suatu rangkaian elektronik pengaman hubung singkat. Berfokus pada pengaman untuk tegangan searah yang nantinya digunakan untuk modul rangkaian elektronik pada media pembelajaran yang terdapat disekolah ataupun di perguruan tinggi.

\section{METODE}

Penelitian dilakukan di Laboratorium Elektronika Daya Jurusan Pendidikan Teknik Elektro Fakultas Teknik Universitas Negeri Yogyakarta. Pengembangan alat telah dilakukan pada tahun 2015 dan pada tanggal 2- 
6 April 2018 dilakukan analsisis terhadap kecepatan respon sensor tegangan dengan memvariasi zener diode sebagai tegangan referensi sensor komparator. Tahapan penelitian menggunakan metode Penelitian Pengembangan yang terdiri dari dari analisis kebutuhan pengaman hubung singkat Modul Rangkaian Elektronik untuk pemebelajaran mikrokontroller, perancangan sistem deteksi tegangan hubung singkat, pembuatan rangkaian, pengujian rangkaian dan implementasi rangkaian.

Tahapan analisis kebutuhan meliputi spesifikasi tegangan yang akan diamankan dari hubung sikat adalah tegangan searah sebsesar $5 \mathrm{~V}$ dan $12 \mathrm{~V}$ terstabilkan. Sistem yang dirancang harus mampu untuk dapat memutus jalur tegangan catu seketika ke beban apabila terjadi hubung singkat. Selain itu harus memiliki tanda kepengguna apabila terjadi hubung singkat pada tegangan diseluruh rangkaian.

Tahapan perancangan menggunakan bantuan software simulasi yang mampu menggambarkan cara kerja dari desain rangkaian yang dibuat. Software tersebut adalah simulasi ISIS Proteus Profesional 8.0 yang memiliki kemampuan untuk mensimulasikan dari kerja rangkaian elektronik.

Tahapan pembuatan dimulai dari perancangan desain PCB menggunakan software ARES Proteus Profesional 8.0. Selanjutnya, desain PCB disablon ke PCB polos, untuk selanjutnya dilakukan proses pelarutan, pelubangan dan finishing. Setelah PCB selesai dibuat, dilakukanlah pemasangan dan peyolderan seluruh komponen.

Tahapan pengujian rangkaian menggunakan multi pengujian pada tegangan referensi sensor tegangan komparator. Variasi tegangan didapatkan dari penggunaan besaran zener diode yang difariasi, mulai dari $2.7 \mathrm{~V}$ sampai dengan 10V. Tujuannya adalah agar memperoleh suatu kesimpulan penggunaan zener diode yang tepat dengan melihat respon kerja dari rangkaian pengaman hubung singkat yang paling baik.

Tahapan terakhir yaitu penerapan yang dilakukan pada Modul Rangkaian Elektronik untuk pembelajaran mikrokontroler. Setiap modul menggunakan pengaman hubung singkat ini pada tengan $5 \mathrm{~V}$ dan $12 \mathrm{~V}$ DC dengan arus sumber sebesar $1 \mathrm{~A}$.

\section{HASIL DAN PEMBAHASAN}

Tahapan pengembangan pertama yaitu dimulai dari perancangan rangkaian elektronik pengaman hubung singkat untuk tegangan searah. Perancangan rangkaian menggunakan komponen aktif komparator LM358 yang memiliki 2 komparator dalam satu kemasan IC. Hal ini cukup untuk membuat dua macam pengaman tegangan dari hubung singkat mengunakan 1 buah IC. Selain itu LM358 dapat bekerja pada tegangan tunggal, yaitu positif dan ground (tidak memerlukan tegangan negatif). Output komparator LM358 mampu memicu transistor BD138. Sehingga tidak perlu membutuhkan transistor buffer lagi.

Guna memutus dan menghubungkan jalur tegangan kebeban, dirancang suatu rangkaian menggunakan relay yang memiliki satu pusat (masukan) kontaktor dan dua keluaran kontaktor. Hal ini dipilih karena dua kontaktor keluaran digunakan, satu kontaktor keluaran terhubung pada sumber tegangan beban, dan satu kontaktor keluaran lagi terhubung ke masukan sensor tegangan komparator. Kontaktor yang terhubung pada masukan inverting kontaktor digunakan untuk mengunci tegangan agar selalu mendeteksi terjadinya hubung singkat, selama jaringan masih tetap hubung singkat menunggu untuk diputus pada titik yang terindikasi hubung singkat. Selain itu relay memiliki kemampuan untuk memutus dan menghubung dengan arus yang besar. Rangkaian ini dirancang untuk memperoleh kerja sehingga rangkaian dapat bertahan lama, karena secara teori bahwa tegangan hubung singkat memiliki arus besar. 
Buzzer dimasukkan dalam rancangan elektronik untuk memberikan tanda berupa bunyi saat terjadi hubung singkat. Secara umum, pengguna modul pembelajaran akan lebih cepat merespon apabila menggunakan sinyal-sinyal berupa cahaya dan bunyi. Diharapkan bunyi yang timbul saat terjadi hubung singkat, memberikan sinyal untuk diambil tindakan segera melepas titik yang diprediksi penyebab terjadinya hubung singkat.

Komponen penting yang menentukan kecepatan respon sensor tegangan komparator adalah diode zener. Diode zener digunakan untuk membatasi atau menentukan tegangan referensi dari komparator. Pada penelitian pengembangan ini diode zener akan divariasi, mulai dari $2.7 \mathrm{~V}$ sampai dengan $10 \mathrm{~V}$. Variasi zener dilakukan untuk mendapatkan data yang spesifik terkait dengan kecepatan respon dari sensor tegangan komparator. Data yang diperoleh dicatat dan digunakan untuk menentukan zener yang paling tepat untuk mendapatkan respon pengaman hubung singkat yang paling cepat. Berikut rancangan rangkaian elektronik pengaman hubung singkat tegangan searah.

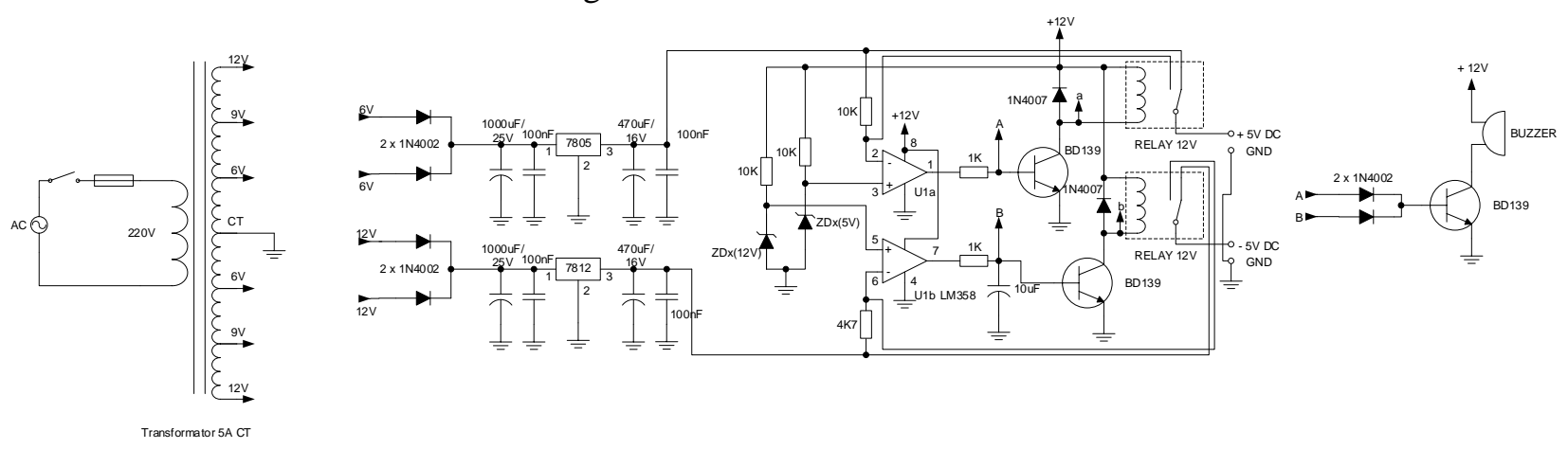

Gambar 1. Rangkaian pengaman hubung singkat tegangan searah

Setelah melalui tahapan perancangan rangkaian dan menggunakan bantuan perangkat lunak untuk mensimulasikan kerja dari rangkaian, maka tahapan berikutnya adalah pembuatan dari perangkat keras rangkaian tersebut. Rangkaian yang dibuat menggunakan tata letak yang didisain sesuai dengan kaidah pembuatan rangkaian. Kaidah yang diterapkan meliputi penataan terminal hubung rangkaian berada di tepi, penggunaan aluminium pendingin untuk komponen aktif IC regulator serta tata letak pendingin dengan komponen lain dan komponen aktif lain memiliki jarak yang aman. Berikut hasil dari pembuatan perangkat keras dari rangkaian pengaman hubung singkat tengan DC.

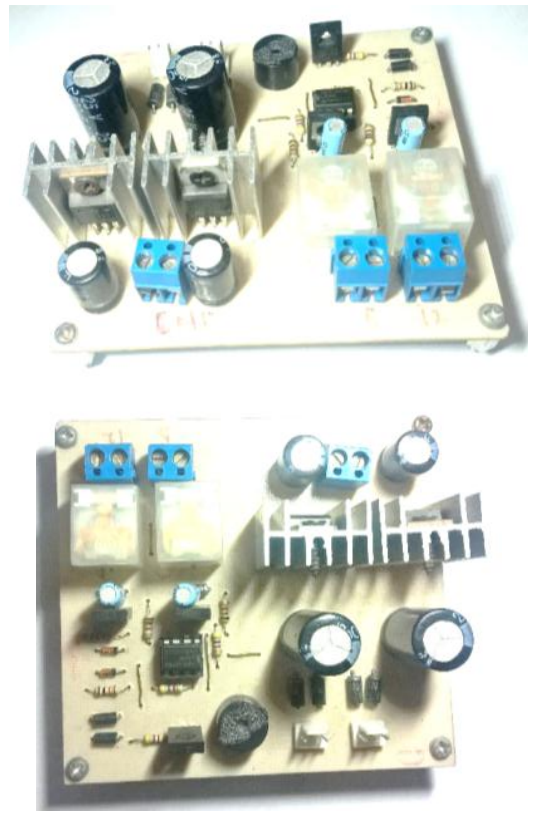

Gambar 2. Rangkaian pengaman hubung singkat tegangan searah

Diode zener pada perangkat keras rangkaian pengaman hubung singkat dilepas, dan di buat untuk memudahkan dalam 
pemasangan dan penggantian nilai diode yang terpasang. Tahapan ini digunakan untuk mendapatkan data kecepatan renspon dari sensor deteksi hubung singkat. Data yang diperoleh dari beberapa kali percobaan disajikan dalam tiga buah tabel sebagai berikut:

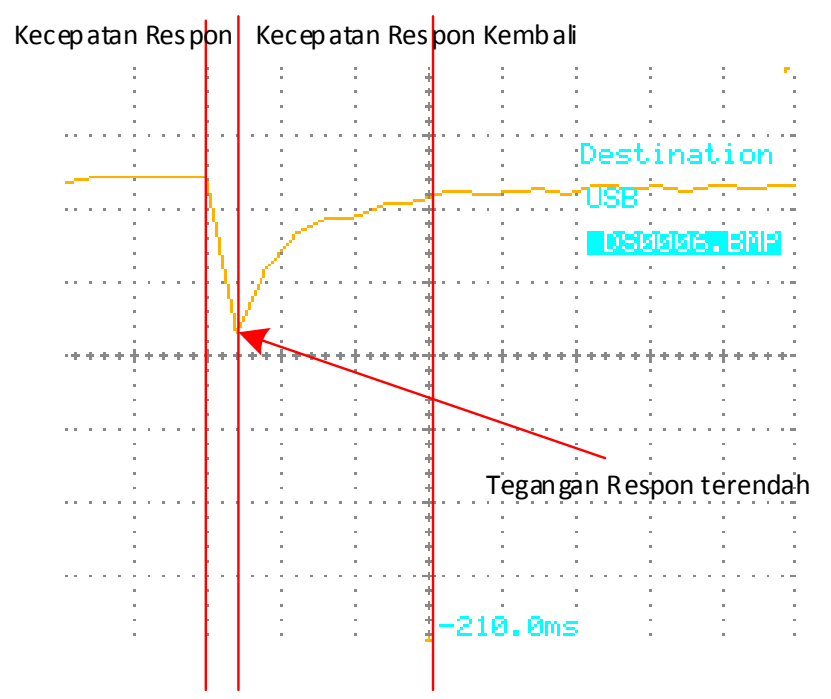

Gambar 3. Karakteristik pembacaan data pada grafik CRO

Nilai besaran kecepatan dan tegengan dibaca menggunakan acuan seperti gambar 3 . Grafik dibagi menjadi dua bagian kecepatan respon, yaitu kecepatan respon kerja yang terlihat dari bentuk gelombang tinggi ke rendah dan kecepatan respon kembali pada tegangan normal yang terlihat dari gelombang rendah/bawah menuju tinggi. Sedangkan titik tegangan terendah diambilkan pada paling dasar lembah dari bentuk gelombang.

Tabel 1. Kecepatan respon kerja rangkaian komparator

\begin{tabular}{|c|c|c|c|c|c|c|c|c|c|c|c|c|c|c|}
\hline \multirow{3}{*}{$\begin{array}{l}\text { Data } \\
\text { Nomor }\end{array}$} & \multicolumn{14}{|c|}{ Waktu Respon Kerja Rangkaian Komparator (Falling Edge) (ms) } \\
\hline & \multicolumn{2}{|c|}{ Zener $2,7 \mathrm{~V}$} & \multicolumn{2}{|c|}{ Zener 3,3V } & \multicolumn{2}{|c|}{ Zener 3,9V } & \multicolumn{2}{|c|}{ Zener $4,7 \mathrm{~V}$} & \multicolumn{2}{|c|}{ Zener 5,6V } & \multicolumn{2}{|c|}{ Zener $7,5 \mathrm{~V}$} & \multicolumn{2}{|c|}{ Zener $10 \mathrm{~V}$} \\
\hline & $\begin{array}{c}\text { Reg } \\
5 \mathrm{~V}\end{array}$ & $\begin{array}{l}\text { Reg } \\
12 \mathrm{~V}\end{array}$ & $\begin{array}{c}\text { Reg } \\
5 \mathrm{~V}\end{array}$ & $\begin{array}{l}\text { Reg } \\
12 \mathrm{~V}\end{array}$ & $\begin{array}{c}\text { Reg } \\
5 \mathrm{~V}\end{array}$ & $\begin{array}{l}\text { Reg } \\
12 \mathrm{~V}\end{array}$ & $\begin{array}{c}\text { Reg } \\
5 \mathrm{~V}\end{array}$ & $\begin{array}{l}\text { Reg } \\
12 \mathrm{~V}\end{array}$ & $\begin{array}{c}\text { Reg } \\
5 \mathrm{~V}\end{array}$ & $\begin{array}{l}\text { Reg } \\
12 \mathrm{~V}\end{array}$ & $\begin{array}{c}\text { Reg } \\
5 \mathrm{~V}\end{array}$ & $\begin{array}{l}\text { Reg } \\
12 \mathrm{~V}\end{array}$ & $\begin{array}{c}\text { Reg } \\
5 \mathrm{~V}\end{array}$ & $\begin{array}{l}\text { Reg } \\
12 \mathrm{~V}\end{array}$ \\
\hline 1 & 4 & 8 & 4 & 4 & 4 & 4 & 4 & 4 & $\mathrm{x}$ & 4 & $\mathrm{x}$ & 4 & $\mathrm{x}$ & 4 \\
\hline 2 & 4 & 8 & 4 & 4 & 4 & 4 & 4 & 4 & $\mathrm{x}$ & 4 & $\mathrm{x}$ & 4 & $\mathrm{x}$ & 4 \\
\hline 3 & 4 & 4 & 4 & 4 & 4 & 4 & 4 & 4 & $\mathrm{x}$ & 8 & $\mathrm{x}$ & 4 & $\mathrm{x}$ & 4 \\
\hline 4 & 4 & 4 & 4 & 4 & 4 & 4 & 4 & 4 & $\mathrm{x}$ & 4 & $\mathrm{x}$ & 4 & $\mathrm{x}$ & 4 \\
\hline 5 & 4 & 8 & 4 & 4 & 4 & 4 & 4 & 4 & $\mathrm{x}$ & 4 & $\mathrm{x}$ & 8 & $\mathrm{x}$ & 4 \\
\hline $\begin{array}{c}\text { Rata- } \\
\text { rata }\end{array}$ & 4 & 6.4 & 4 & 4 & 4 & 4 & 4 & 4 & $\mathrm{x}$ & 4.8 & $\mathrm{x}$ & 4.8 & $\mathrm{x}$ & 4 \\
\hline
\end{tabular}

Nilai tegangan zener yang digunakan untuk $5 \mathrm{~V}$ tegangan regulasi sebesar $2.7 \mathrm{~V}$ sampai dengan 4.7V. Apabila zener bertegangan lebih dari $5 \mathrm{~V}$ maka, sensor tegangan berupa komparator akan aktif selalu, sehingga pada tabel diberikan simbol x. Ratarata data yang diperoleh menunjukkan waktu respon sensor hubung singkat sebesar $4 \mathrm{~ms}$ sebelum relay bekerja untuk memutus tegangan yang terindikasi terjadi hubung singkat. Untuk mendapatkan data yang akurat, maka percoban hubung singkat dilakukan sebanyak 5 kali pada setiap besaran tegengan zener. 
Tabel 2. Kecepatan respon Kembali kondisi tegangan normal pada rangkaian komparator

\begin{tabular}{|c|c|c|c|c|c|c|c|c|c|c|c|c|c|c|}
\hline \multirow{3}{*}{$\begin{array}{l}\text { Data } \\
\text { Nomor }\end{array}$} & \multicolumn{14}{|c|}{ Waktu Respon Kembali Kondisi Tegangan Normal pada Rangkaian (Rising Edge) (ms) } \\
\hline & \multicolumn{2}{|c|}{ Zener $2,7 \mathrm{~V}$} & \multicolumn{2}{|c|}{ Zener 3,3V } & \multicolumn{2}{|c|}{ Zener $3,9 \mathrm{~V}$} & \multicolumn{2}{|c|}{ Zener $4,7 \mathrm{~V}$} & \multicolumn{2}{|c|}{ Zener $5,6 \mathrm{~V}$} & \multicolumn{2}{|c|}{ Zener $7,5 \mathrm{~V}$} & \multicolumn{2}{|c|}{ Zener $10 \mathrm{~V}$} \\
\hline & $\begin{array}{c}\text { Reg } \\
5 \mathrm{~V}\end{array}$ & $\begin{array}{l}\text { Reg } \\
12 \mathrm{~V}\end{array}$ & $\begin{array}{c}\text { Reg } \\
5 \mathrm{~V}\end{array}$ & $\begin{array}{l}\text { Reg } \\
12 \mathrm{~V}\end{array}$ & $\begin{array}{l}\text { Reg } \\
5 \mathrm{~V}\end{array}$ & $\begin{array}{l}\text { Reg } \\
12 \mathrm{~V}\end{array}$ & $\begin{array}{c}\text { Reg } \\
5 \mathrm{~V}\end{array}$ & $\begin{array}{l}\text { Reg } \\
12 \mathrm{~V}\end{array}$ & $\begin{array}{l}\text { Reg } \\
5 \mathrm{~V}\end{array}$ & $\begin{array}{l}\text { Reg } \\
12 \mathrm{~V}\end{array}$ & $\begin{array}{l}\text { Reg } \\
5 \mathrm{~V}\end{array}$ & $\begin{array}{l}\text { Reg } \\
12 \mathrm{~V}\end{array}$ & $\begin{array}{c}\text { Reg } \\
5 \mathrm{~V}\end{array}$ & $\begin{array}{l}\text { Reg } \\
12 \mathrm{~V}\end{array}$ \\
\hline 1 & 4 & 42 & 4 & 26 & 4 & 26 & 4 & 20 & $\mathrm{x}$ & 16 & $\mathrm{x}$ & 16 & $\mathrm{x}$ & 12 \\
\hline 2 & 4 & 42 & 4 & 26 & 4 & 26 & 4 & 22 & $x$ & 18 & $\mathrm{x}$ & 16 & $\mathrm{x}$ & 16 \\
\hline 3 & 4 & 46 & 4 & 26 & 4 & 26 & 4 & 20 & $\mathrm{x}$ & 12 & $\mathrm{x}$ & 20 & $\mathrm{x}$ & 16 \\
\hline 4 & 4 & 46 & 4 & 26 & 4 & 26 & 4 & 20 & $\mathrm{x}$ & 16 & $\mathrm{x}$ & 16 & $\mathrm{x}$ & 16 \\
\hline 5 & 4 & 42 & 4 & 26 & 4 & 26 & 4 & 20 & $\mathrm{x}$ & 16 & $\mathrm{x}$ & 12 & $\mathrm{x}$ & 16 \\
\hline $\begin{array}{c}\text { Rata- } \\
\text { rata }\end{array}$ & 4 & 43.6 & 4 & 26 & 4 & 26 & 4 & 20.4 & $\mathrm{x}$ & 15.6 & $\mathrm{x}$ & 16 & $\mathrm{x}$ & 15.2 \\
\hline
\end{tabular}

Sedangkan untuk kecepatan rangkaian dalam mengembalikan tegangan hubung singkat pada besaran tegangan normal $(5 \mathrm{~V}$ atau $12 \mathrm{~V}$ DC) memperoleh hasil yang bervariasi, terutama pada sensor hubung singkat yang mendeteksi tegangan terstabilkan sebesar $12 \mathrm{~V}$.
Pada tegangan terstabilkan $5 \mathrm{~V}$ relatif memiliki kecepatan waktu yang sama, yaitu sebesar 4ms. Pada data kecepatan respon tegangan kembali terstabilkan $12 \mathrm{~V}$ semakin besar mendekati $10 \mathrm{~V}$, hasil kecepatan semakin kecil mencapai ratarata $16 \mathrm{~ms}$.

Tabel 3. Tegangan respon terendah

\begin{tabular}{|c|c|c|c|c|c|c|c|c|c|c|c|c|c|c|}
\hline \multirow{3}{*}{$\begin{array}{l}\text { Data } \\
\text { Nomor }\end{array}$} & \multicolumn{14}{|c|}{ Tegangan Respon Terendah (V) } \\
\hline & \multicolumn{2}{|c|}{ Zener 2,7V } & \multicolumn{2}{|c|}{ Zener 3,3V } & \multicolumn{2}{|c|}{ Zener 3,9V } & \multicolumn{2}{|c|}{ Zener 4,7V } & \multicolumn{2}{|c|}{ Zener 5,6V } & \multicolumn{2}{|c|}{ Zener $7,5 \mathrm{~V}$} & \multicolumn{2}{|c|}{ Zener 10V } \\
\hline & $\begin{array}{l}\text { Reg } \\
5 \mathrm{~V}\end{array}$ & $\begin{array}{l}\text { Reg } \\
12 \mathrm{~V}\end{array}$ & $\begin{array}{l}\text { Reg } \\
5 \mathrm{~V}\end{array}$ & $\begin{array}{l}\text { Reg } \\
12 \mathrm{~V}\end{array}$ & $\begin{array}{c}\text { Reg } \\
5 \mathrm{~V}\end{array}$ & $\begin{array}{l}\text { Reg } \\
12 \mathrm{~V}\end{array}$ & $\begin{array}{c}\text { Reg } \\
5 \mathrm{~V}\end{array}$ & $\begin{array}{l}\text { Reg } \\
12 \mathrm{~V}\end{array}$ & $\begin{array}{c}\text { Reg } \\
5 \mathrm{~V}\end{array}$ & $\begin{array}{l}\text { Reg } \\
12 \mathrm{~V}\end{array}$ & $\begin{array}{l}\text { Reg } \\
5 \mathrm{~V}\end{array}$ & $\begin{array}{l}\text { Reg } \\
12 \mathrm{~V}\end{array}$ & $\begin{array}{c}\text { Reg } \\
5 \mathrm{~V}\end{array}$ & $\begin{array}{l}\text { Reg } \\
12 \mathrm{~V}\end{array}$ \\
\hline 1 & 0.6 & 3.5 & 1 & 2 & 1.4 & 4 & 1 & 2 & $\mathrm{x}$ & 3.5 & $\mathrm{x}$ & 1.5 & $\mathrm{x}$ & 1 \\
\hline 2 & 1 & 3.5 & 2 & 3 & 1.2 & 1 & 3.5 & 3.5 & $\mathrm{x}$ & 3 & $\mathrm{x}$ & 4 & $\mathrm{x}$ & 1 \\
\hline 3 & 1.8 & 1.5 & 2.4 & 1.5 & 2 & 1 & 1 & 2 & $\mathrm{x}$ & 6 & $\mathrm{x}$ & 4 & $\mathrm{x}$ & 2.5 \\
\hline 4 & 1.8 & 1.5 & 3.6 & 2.5 & 1.4 & 2 & 1 & 3.5 & $\mathrm{x}$ & 3.5 & $\mathrm{x}$ & 2 & $\mathrm{x}$ & 1.5 \\
\hline 5 & 0.4 & 3.5 & 2.8 & 2 & 1 & 3 & 1 & 3.5 & $\mathrm{x}$ & 4 & $\mathrm{x}$ & 2.5 & $\mathrm{x}$ & 1.5 \\
\hline $\begin{array}{c}\text { Rata- } \\
\text { rata }\end{array}$ & 1.12 & 2.7 & 2.36 & 2.2 & 1.4 & 2.2 & 1.5 & 2.9 & $\mathrm{x}$ & 4 & $\mathrm{x}$ & 2.8 & $\mathrm{x}$ & 1.5 \\
\hline
\end{tabular}

Saat terjadi hubung singkat memiliki karakteristik terjadi penurunan tegangan mendekati nol atau groud. Apabila tegangan positif terjadi hubung singkat dan nilai besarnya tegangan sama dengan ground dalam waktu lama akan membuat komponen penyetabil tegangan rusak. Hal itulah yang harus dihindari dari proses terjadinya hubung singkat. Dengan mendeteksi tegangan terendah seperti tabel 3, dapat ditentukan kerja sensor deteksi yang paling aman untuk digunakan. Semakin besar tegangan respon saat hubung singkat, maka rangkaian catu daya pada Modul Rangkaian Elektronik untuk pemebelajaran lebih aman. Pada tabel 3 diatas respon tegangan terendah yang paling besar adalah $6 \mathrm{~V}$, dan respon tegangan terendah paling kecil adalah $0.6 \mathrm{~V}$.
Tegangan terendah ini diambil dari tegangan lembah paling dasar dari grafik respon rangkaian terhadap hubung singkat tegangan searah. Dari sumber tegangan $12 \mathrm{~V}$ dan $5 \mathrm{~V}$ memiliki perbedaan yang tidak signifikan. Data yang diperoleh berkisaran antara $1 \mathrm{~V}$ sampai dengan $5 \mathrm{~V}$ walaupun sudah divariasi nilai tegangan zener. Karakteristik yang diperoleh, semakin besar tegangan zener dinaikkan, maka akan diikuti semakin besar pula tegangan terendah, walaupun kenaikannya tidak signifikan.

Sebagai rangkaian pengaman hubung singkat tegangan searah yang dilengkapi dengan tanda pemberitahuan hubung singkat berupa bunyi dari buzzer telah bekerja sesuai dengan perancangan awal. Setiap dilakukan 
pengujian hubung singkat, buzzer akan bekerja dan sistem pengaman bekerja dengan memutus jalur tegangan catu daya yang terindikasi terjadi hubung singkat. Kecepatan respon dimasing masing tegangan terstabilkan dapat dibagi menjadi dua, yaitu kecepatan respon untuk tegangan 5VDC dan tegangan respon untu 12VDC.

Rangkaian pengaman hubung singkat untuk tegangan 5VDC memiliki kecepatan respon kerja terbaik $4 \mathrm{~ms}$ dan respon kembali pada tegangan normal 4ms. Data tersebut menunjukkan kecepatan sistem untuk mendeteksi dan merespon dalam melakukan pengamanan apabila terjadi hubung singkat telah bekerja dengan baik. Tegangan terendah saat terjadi hubung singkat dan kemudia direspon dengan aktifnya pengaman pada tegangan $3.6 \mathrm{~V}$ dengan diode zener referensi 3.3V. Tegangan terendah yang terdeteksi semakin jauh dari nilai besaran tegangan ground (0), maka kerja rangkaian sangat bagus.

Berikut bentuk gelombang respon kinerja yang baik dari pengeman hubung singkat dengan tegangan referensi diode zener 3.3V.

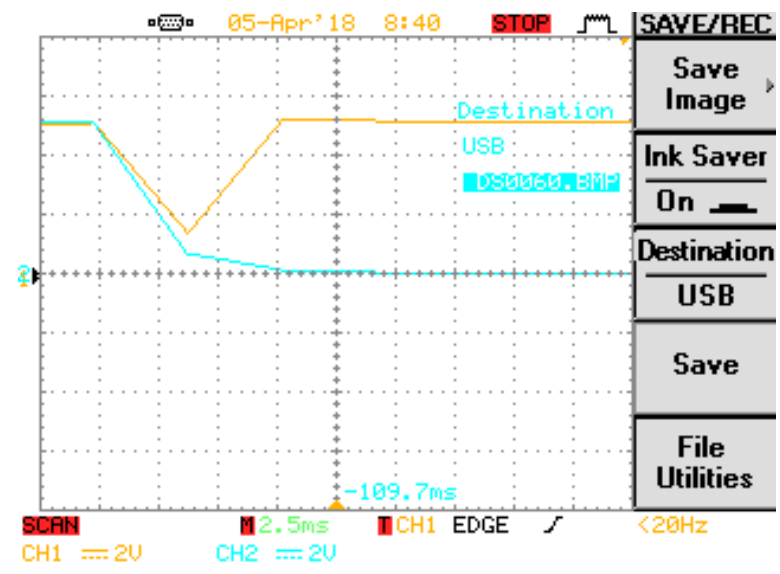

Gambar 4. Grafik tegangan sinyal respon pengaman hubung singkat pada tengan 5VDC

Garis warna orange (membentuk huruf "V") menunjukan kecepatan respon dan kecepatan kembali tegangan pada keluaran IC penyetabil tegangan saat terjadi hubung singkat. Garis warna biru menunjukkan bahwa relay bekerja untuk memutus jalur tegangan yang diidentifikasi sensor bermasalah. Walaupun menggunkan sistem mekanik untuk memutusnya, tetapi membutuhkan waktu untuk mencapai 0 tegangan (sama dengan ground).

Rangkaian pengaman hubung singkat untuk tegangan 12VDC memiliki kecepatan respon terbaik $4 \mathrm{~ms}$ dan kecepatan respon kembali pada tegangan normal $12 \mathrm{~ms}$. Kecepatan respon kembali ini jauh lebih lama dibandingkan untuk pengaman hubung singkat tegangan $5 \mathrm{~V}$, yaitu $4 \mathrm{~ms}$. Hal ini dikarenakan semakin besar tegangan, proses pengisian dan kembalinya pada tegangan normal membutuhkan waktu. Seperti prinsip pada komunikasi data, dibutuhkan resistor pull up untuk membantu mempercepat kecepatan sinyal naik (rising edge).

Tegangan terendah dari sensor pengaman hubung singkat pada tegangan terstabilkan $12 \mathrm{~V}$ yaitu sebesar $6 \mathrm{~V}$ pada tegangan referensi diode zener 5.6V. Walaupun diode zener diperbesar, tetapi nilai tegangan terendah terbaik berada pada zener 5.6V. Berikut gambar sinyal kecepatan respon pada tegangan terstabilkan $12 \mathrm{~V}$.

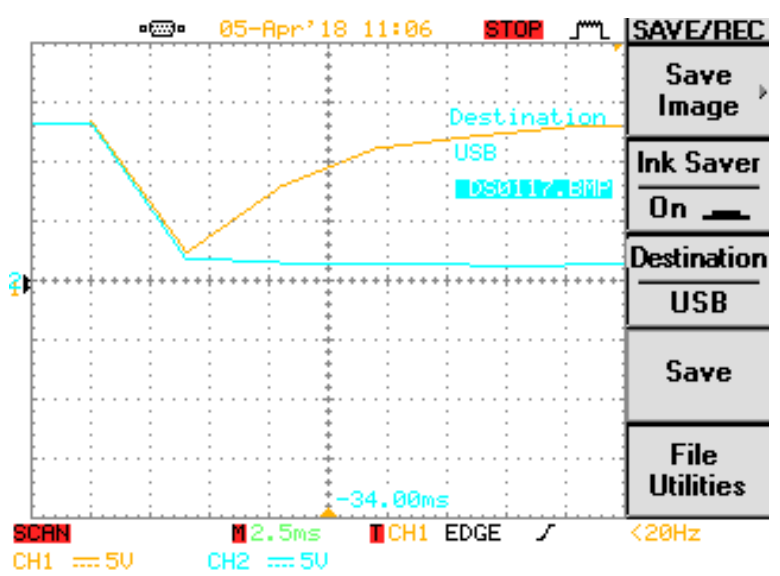

Gambar 5. Grafik tegangan sinyal respon pengaman hubung singkat pada tengan $12 \mathrm{VDC}$

Garis warna orange (membentuk huruf "V") menunjukan kecepatan respon dan kecepatan kembali tegangan pada keluaran IC penyetabil tegangan saat terjadi hubung singkat. Walaupun kecepatan respon kembali lebih lama dari pada kecepatan respon kerja, tetapi masih dalam respon yang cepat, yaitu sebesar $16 \mathrm{~ms}$. Garis warna biru menunjukkan bahwa relay 
bekerja untuk memutus jalur tegangan yang diidentifikasi sensor bermasalah. Walaupun menggunkan sistem mekanik untuk memutusnya, tetapi membutuhkan waktu untuk mencapai 0 tegangan (sama dengan ground).

\section{SIMPULAN}

Penarikan kasimpulan dari penelitian pengembangan yang dilakukan adalah: Rangkaian bekerja dengan baik, yaitu ditandai dengan kerja relay saat terjadinya hubung singkat dan dibarengi dengan kerja dari buzzer yang mengeluarkan bunyi. Jumlah kecepatan respon terbaik untuk tegangan terstabilkan $5 \mathrm{~V}$ adalah $8 \mathrm{~ms}$ yaitu pada zener $3.3 \mathrm{~V}$, dan jumlah kecepatan respon terbaik untuk tegangan terstabilkan $12 \mathrm{~V}$ adalah $16 \mathrm{~ms}$ yaitu pada zener 5.6V. Penggunaan diode zener yang tepat mempengaruhi kinerja dari kecepatan rangkaian pengaman dalam bekerja.

\section{DAFTAR RUJUKAN}

Gavrilovs, Gerards; Vitolina, Sandra. Identification of Power Transformer's Failure and Risk Source. Proceedings of the 52st Annual International Scientific Conference of Riga Technical Universty Section Power and Electrical Engginering, October 2011: date accessed 10 Apr 2018
Heinich, Robert (2001). Instructional Media and technology for Learning Seventh Edition; Merrill Prentice Hall, New Jersey.

Neha; Yadav, Amana; Chaudhary, Ila. Design and Analysis of Comparation 180nm CMos Technology. IJECT Journal Vol.7, Issue 2, April-Jun 2016. ISSN Online 2230-7190. www.iject.org/vol72/25neha.pdf; date accessed 10 Apr 2018.

MUSTHOLIQ, Imam; SUKIR, Sukir; N., Ariade Chandra. Pengembangan Media Pembelajaran Interaktif Berbasis Multimedia Mata Kuliah Dasar Listrik. Jurnal Pendidikan Teknologi dan Kejuruan, [S.1.], v. 16, n. 1, p. 1-18, may 2016. ISSN 2477-2410. Available at: <https://journal.uny.ac.id/index.php/jptk/ article/view/9310/7578>. Date accessed 04 apr. 2018. doi:http://dx.doi.org/10.21831/jptk.v16i1. 9310.

Wang, Yang; Zai, Xiaoshe; Song, Zhenxiang; Geng, Yingsan. A new method to detect the short circuit current in DC supply system based on the flexible Rogowski coil. Electric Power Equipment Switching Technology (ICEPE-ST), 2011 first International Conference. Accses on: https://ieeexplore.ieee.org/document/612 2978/ at 10 Apr 2018. 